FACULDADE DE CIÊNCIAS ECONÔMICAS dA UFRGS

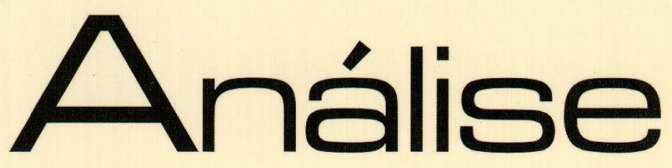

CRISES CAMBIAIS DOS ANOS 1990: UMA ANÁLISE SOB O ENFOQUE CUSTO BENEFICIO Ȧ BARRO-CORDON

TITO BELCHIOR S. MOREIRA, MAURÍCIO BARATA DE P. PINTO, GERALDO DA SILVA E SOUZA

LEI FUNDAMENTAL DA CONCORRÉNCIA CAPITALISTA E CRITÉRIO DE ADOCAO DE NOVAS TÉCNICAS

FRANCISCO PAULO CIPOLLA

CONCORRENCIA COMPORTAMENTO ESTRATÉGICO E. DESEMPENHO COMPETITIVO

ACHYLES BARCELOS DA COSTA

INCENTIVOS FISCAIS ISUDAM E SUFRAMA) E A DINÁMICA INDUSTRIAL E AGROPECUÁRIA NA REGIĀOO NORTE

LUIZ ROBERTO C. NASCIMENTO, IOÁO POLICARPO R. LIMA

VANTAGENS COMPARATIVAS MUNICIPAIS: INDICADORES E DETERMINANTES

MARCOS COSTA HOLANDA, FRANCIS CARIO PETTERINI

A CONTRIBUIÇÃO DO EMPRECO PÚBUICO NA GERAÇÃO DE POSTOS DE TRABALHO NOS PAISES DESENVOLVIDOS DESDE O POS CUERRA

FERNANDO AUCUSTO M. DE MATIOS

THE UIP HYPOTHESIS FOR ARCENTINA, BRAZIL, CHILE AND MEXICO WITH THE USE OF THE RATIONAI EXPECTAIION HYPOTHESIS. NEW EMPIRICAL EVIDENCE

JAIMILTON V CARVALHO, ADOLFO SACHSIDA, PAULO R. A. LOUREIRO, TIO BELCHIOR S. MOREIRA

A REUUGÁG UA JURNALA DE IRABAL HO EM MARX: POR QUE FALHAM AS PREVISÓES NOVO-KEYNESIANAS SOBRE OS IMPACTOS DESSA MEDIDA?

PAULO SÉRGIO FRACALANZA

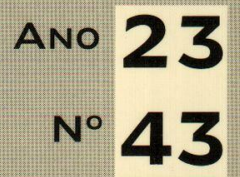

Março, 2005 
Universidade federal. do Rio Grande do Sul Reitor Prof. José Carlos Ferraz Hennemann

Faculdade de Ciências Econômicas

Diretor: Prof. Gentil Corazza

Centro de Estudos e Pesquisas Econômtcas

Diretor: Prof Lovois de Andrade Miguel

Departamento de Ciências Econômicas

Chefe: Prof. Ricardo Dathein

Departamento de Ciências Coniábeis e Atuariais

Chefe: Prof. Ceno Odilo Kops

Curso de Pós-Graduaçao em Economia

Coordenador: Prof. Femando Ferrari Filho

Curso de Pós-Graduação em Desenvolvimento

RuRAt.

Coordenador: Prof. Paulo Dabdab Waquil

Conseino Editorial: Carlos G A. Mielitz Netto (UFRGS), Eduardo A Maldonado Filho(UFRGS), Eduardo P. Ribeiro(UFRGS), Eleutério F. S. Prado (USP), Eugênio Lagemann (UFRGS), Fernando Cardim de Carvalho (UFRJ), Fernando Ferrari Filho (UFRGS), Fernando de Holanda Barbosa (FGV/RJ), Flávio Vasconcellos Comim (UFRGS), Gentil Corazza (UFRGS), Giácomo Balbinotto Netto (UFRGS), Gustavo Franco (PUC/RJ), Hélio Henkin (UFRGS), Jan A Kregel (UNCTAD), João Rogério Sanson(UFSC), Joaquim Pinto de Andrade (UnB), Jorge Paulo Araujo (UFRGS), Marcelo S. Portugal (UFRGS), Maria Alice Lahorgue (UFRGS), Paul Davidson (University of Tennessee), Paulo D. Waquil (UFRGS), Pedro C. D. Fonseca (UFRGS), Philip Arestis (University of Cambridge), Roberto C. Moraes (UFRGS), Ronald Otto Hillbrecht (UFRGS), Sérgio M. M. Monteiro (UFRGS), Sabino da Silva Porto Jr (UFRGS), Stefano Florissi (UFRGS) e Werner Baer (University of IHinois at Urbana - Champaign).

Comissão Enitorial: Eduardo Augusto Maldonado Filho, Fernando Ferrari Filho, Hélio Henkin, Marcelo Savino Portugal, Paulo Dabdab Waquil e Sérgio Marley Modesto Monteiro.
Eøiror: Sérgio Marley Modesto Monteiro

Eorror Adjunto: Hélio Henkin

Secretário: Emerson Douglas Neves

Revisĩo DE TEXros: Vanete Ricacheski.

Editoração: Núcleo de Editoração e Criaçâo da Gráfica da UFRGS - Janaína Horn e Junia Saedt

Fundador: Prof. Antônio Carlos Santos Rosa

Os materiais publicados na revista Análise Econômica são da exclusiva responsabilidade dos autores. É. permitida a reprodução total ou parcial dos trabalhos, desde que seja citada a fonte. Aceita-se permuta com revistas congêneres Aceitam-se, também, livros para divulgação, elaboração de resenhas e recensões. Toda correspondencia, material para publicação (vide normas na terceira capa), assinaturas e permutas devem ser dirigidos ao seguinte destinatário:

Prof. Sérgio Marley Modesto Monteiro Revista Analuse Económica - Av. João Pessoa, 52 CEP 90040-000 PORTO ALEGRE - RS, BRASIL. Telefones: (051) $33163513 / 33164164$ Fax: (051) 33163990 - E-mail: rae@vortex ufrgs.br

A Revista Análise Econômica agradece a colaboração dos pareceristas do número 43 , abaixo relacionados:

Adelar Fochezatto

Carlos Henrique Horn

Carlos Guilherme A. Mielitz Netto

Fabiana Fontes Rocha

Márcio Gomes Pinto Garcia

Maria de Lourdes Rollemberg Mollo

Maria Luiza Falcão Silva

Orlando Martinelli $\mathbf{J} \mathbf{r}$

Ricardo Dathein

Sabino da Silva Porto Jr

Samuel de Abreu Pessoa

Sérgio Marley Modesto Monteiro

\section{Análise Econômica}

Ano 23, n 43, março, 2005 - Porto Alegre

Faculdade de Ciências Econômicas, UJRGS, 2000

Periodicidade semestral, março e setembro.

1. Teoria Econômica - Desenvolvimento Regional -

Economia Agrícola - Pesquisa Teórica e Aplicada -

Periódicos. I. Brasil.

Faculdade de Ciências Econômicas,

Universidade Federal do Rio Grande do Sul. 


\title{
The UIP hypothesis for Argentina, Brazil, Chile and Mexico with the use of the rational expectation hypothesis: new empirical evidence
}

\author{
Jaimilton V. Carvalho \\ Adolfo Sachsida \\ Paulo R. A. Loureiro \\ Tito Belchior S. Moreira*
}

Resumo: A meta deste estudo é testar a paridade de juros descoberta para a Argentina, Brasil, Chile e México no período de Jan./1990 a Dez./2001, com o uso da hipótese de expectativas racionais. Pretende-se também avaliar o grau de mobilidade de capital estrangeiro nestas jurisdições políticas, usando estimativas de Panel Data, com testes de raízes unitárias propostas por Levin e Lin (1992), e Im, Pesaran, e Shin (1997). Os resultados econométricos indicam a rejeição da UIP, no período estudado, para o grupo formado pela Argentina, Brasil, Chile e México. Contudo, a hipótese da UIP não é rejeitada para o grupo da Argentina, Chile e México no período de Jan./91 a Dez./2000.

Palavras-chave: Paridade Descoberta de Juros, Panel Data, Mobilidade de capital, Teste de Raízes Unitárias.

Abstract: The aim of this study is to test uncovered interest parities for
Argentina, Brazil, Chile, and Mexico, for the Jan/1990 to Dec/2001 period,
with the use of the rational expectation hypothesis. We also intend to
evaluate the degree of mobility of foreign capital in these political
jurisdictions, using panel data estimations, with unit root tests proposed by
Levin and Lin (1992), and Im, Pesaran, and Shin (1997). The econometric
results indicate the rejection of UIP, for the period under study, for the group
comprised of Argentina, Brazil, Chile, and Mexico. However, the UIP
hypothesis is not rejected for the group comprised of Argentina, Chile, and
Mexico for the Jan/1991 to Dec/2000 period.

Keywords: Uncovered Interest Parity, Panel Data, Capital Mobility, Unit Root Test.

JEL: F00, F21

\footnotetext{
* Address for correspondence: Prof. Dr. Tito Belchior S. Moreira, Catholic University of Brasilia - UCB, SGAN 916 - Módulo B - Sala A-117, Brasilia - DF, CEP: 70.790-160 - Tel: (0XX61)3405550 - ramal 188 - Fax: (061)347-4797 - Brazil - E-mail: tito@pos.ucb.br
} 


\section{Introduction}

In recent years, the tendency towards globalization has become increasingly visible, and the political aspects, technology transfer, and financial transactions have become important issues. With favorable conditions for the trading of financial assets over diverse political jurisdictions - due to the possibility of obtaining more attractive capital returns, especially in developing countries, or due to legal flexibility and/or the absence of barriers to incoming long term financial resources - new forms of access to financial resources have been made possible for some of the world's economies.

According to Aliber (1973), assets available in the financial market of different jurisdictions are used to calculate the interest parity that differ in two important attributes - the currency in which they are denominated and political jurisdiction in which they are issued. Differences in the currency lead to cambial risk, that is, the possibility of changes in the exchange rate. Differences in the political jurisdiction lead to political risk, that is, the probability of controlling the capital flow in these jurisdictions in the future.

Montiel (1994) considers the degree of financial openness an amorphous concept, which is not clearly defined in many applications and difficult to measure. A weak definition of complete financial openness is given by a situation where the law of one price rules a specific financial asset, meaning that domestic and foreign residents trade identical assets at the same price. This definition relies on the absence of barriers to capital flow. The strong definition incorporates to the weak one the restriction that assets defined as identical, which may be issued in different political jurisdictions and denominated in different currency, have to be perfect substitutes in every private portfolio. Then, their relative supplies would not affect the relative return rates on those assets, which would naturally eliminate any space for difference on the preferences of domestic and foreign portfolio administrators. In other words, the strong definition given by Montiel, has been used to settle a relation between exchange and interest rates that makes it impossible for the agents to make profits by arbitrage in cambial and bond markets. This can be interpreted as a measure of capital mobility. 
Analytical models suggest that the nature of the relation between domestic and international financial markets (also called the degree of capital mobility) is one of the characteristics of any economy, serving as a determining factor for many basic macroeconomic properties. Domestic and international interest rates, as well as exchange rates, are some of the variables of these models. This article verifies if there is a relation among those variables for Argentina, Brazil, Chile, and Mexico. We test the hypothesis that indicates correlation between the set of domestic interest rates and the comprised set of international interest rates and exchange rates for each country. This result also points the existence of a high degree of capital mobility.

It is common, in theoretical analyses, to inquire about the conditions of arbitrage among these variables, so that relations among them may be established. Empirical studies suggest the existence of Uncovered Interest Parity - UIP, which makes it impossible for agents to profit from arbitrage in exchange and bond markets [Frankel (1992), Montiel (1994), Chinn, and Meredith (2000)]. Thus, it is fundamental to assume the UIP hypothesis in order to obtain an estimate as to the behavior of foreign exchange and interest, thus allowing us to infer other results inherent in each model tested. The UIP test may present several statistical problems when estimating equations, such as, serial correlation of residuals, presence of immeasurable variables, and peso problem [Krasker, 1980].

Specifically for the case of Argentina, Brazil, Chile, and Mexico, when observing annual data for the 1990-2001 period, the presence of immeasurable variables is quite significant for these countries, especially economic/financial variables such as: i) the adoption of distinct exchange regimes (while Argentina maintained a fixed exchange rate from April 1, 1991, through January 6, 2002, Brazil, Chile, and Mexico adopted fixed and floating exchange regimes, with devaluations surpassing 100\%); and ii) significant interest rate differentials, when comparing domestic rates with US rates, indicating that financial agents demand risk premiums for capital brought into these countries.

In this context, the aim of this study is to test the UIP hypothesis for Argentina, Brazil, Chile, and Mexico, for the Jan/ 1990 - Dec/2001 period, with the use of the rational expectation hypothesis. We also intend to further develop the methodological 
aspects of previous studies conducted for these countries, for the period under study, by using panel data and unit root tests as proposed by Levin, and Lin (1992), and Im, Pesaran, and Shin (1997).

We have chosen to work with Latin American countries that stood out in 90's - Argentina, Brazil, Chile, and Mexico - because they are the largest economies of the region. In addition, have experienced common problems, such as high inflation followed by economic stabilization plans, and promoted structural reforms in their economies.

Chinn e Meredith (2000) tested the UIP hypothesis for G-7 countries using panel data techniques. Their results did not reject the validity of the uncovered interest parity for some of these countries. Sachsida, Ellery and Teixeira (2001) tested the UIP hypothesis for the Brazilian economy from 1984 to 1998, finding evidence which favored the hypothesis only during the period of $\mathrm{Jan} / 90$ to Jun/94. Other authors who tested the hypothesis include Baillie and Osterberg (2000), Cristensen (2000), Alexius (2001), Berk and Knot (2001), Flood and Rose (2001) and Francis, Hasan and Hunter (2001).

The article is structured as follows. After this introduction, Section II presents the methodology to be used in the proposed estimation. The analysis of the panel data results is presented in Section III. Our conclusions are then presented in the last section.

\section{Methodology}

From a conceptual standpoint, the derivation of UIP is the result of the arbitrage condition, known as the Covered Interest Parity - CIP, in the future exchange market. Assuming that agents are neutral to risk, implicitly we have that the expected exchange rate variations tend to be equal to the interest differential between domestic rates in the countries under study, and the rate in a reference economy, for example, the US economy.

As proposed by Khor, and Rojas-Suarez (1991), the UIP hypothesis test may be represented by:

$$
(1+i)=\left(1+i_{t}^{*}\right)\left[E\left(\frac{e_{t}+1}{e_{t}}\right)\right]
$$


where: " $i$ " represents the domestic interest rate, " $i$ " the international interest rate, " $E$ " is the mathematical expectation operator, and " $e$ " represents the exchange rate (local currency/US dollar). ${ }^{1}$

By adapting the variables under study to the basic structure of the model proposed by Greene (1997) for estimations using the panel data technique, the UIP hypothesis test for Argentina, Brazil, Chile, and Mexico, using the rational expectations hypothesis, shall be conducted with the following model:

$$
(1+i)_{j t}=\alpha_{j}+\beta^{\prime}\left[\left(1+i^{*}\right)\left(\frac{e_{t+1}}{e_{t}}\right)\right]_{j t}+\varepsilon_{j t}
$$

where: " $i$ " is the nominal domestic interest rate for each country under study, " $i$ " is the nominal international interest rate, and " $e$ " is the exchange rate quotation (local currency/US dollar), and $\alpha$; represents the specific individual effect of each country " $j$ ", which is constant over time and $\varepsilon_{j t}$ is the error term of the regression.

In order to accept the UIP in equation (2.2), the null hypothesis, for which the coefficient of the independent variable is statistically significant and equal to 1 , may not be rejected. In spite of the operational simplicity of the test, many statistical problems arise in the estimation of these models. However, tests that check for uncovered interest parities have been used for several countries, and have been either rejected or accepted.

Before performing the UIP test estimation, we checked for the occurrence of unit roots in the series used in this study, so it would be no possibility of estimating a spurious regression. In Table 2, we have listed the results of the Levin and Lin (LL), and the Im, Pesaran, and Shin (IPS) tests. In order to improve the viewing of the results, the variables in equation (2.2) were named:

$$
(1+i)_{j t}=L T D \text { and }\left[\left(1+i^{*}\right)\left(\frac{e_{t+1}}{e_{t}}\right)\right]_{j t}=L T I \text {. }
$$

The results listed in Table 2 indicated that, in both tests, all the variables used in this study are integrated of order zero (I(0)). ${ }^{2}$

\footnotetext{
${ }^{1}$ See the appendix, Table 1, for a description and source of the data set.

2 This result might be due to the fact that these economies are geographically close (Argentina, Brazil, and Chile) and/or they have similarities for being Latin America countries. These countries, including Mexico, have shown to be sensitive and vulnerable, for instance, to exchange rate and financial crises in the 90's.
} 
We will therefore not be concerned, in this study, with issues relating to spurious regressions, or with issues regarding co-integration.

Table 2: Unit Root Tests for Panel Data

\begin{tabular}{|c|c|c|c|c|c|c|}
\hline Group & Period & $\mathbf{N}$ & $T$ & Variable & LL & IPS \\
\hline $\begin{array}{l}\text { Argertina, Brazil Chile: } \\
\text { Mexico }\end{array}$ & $\begin{array}{l}1990: 01 \text { to } \\
2001: 12\end{array}$ & 4 & 144 & LTD: & $\begin{array}{c}-3.08^{* t} \\
-11.31^{*}\end{array}$ & $\begin{array}{l}-4.32 * t \\
-15.31 * t\end{array}$ \\
\hline Argentina, Chile, Mexico & $\begin{array}{l}1990: 01 \text { to } \\
2001: 12\end{array}$ & 3 & 144 & $\begin{array}{l}\text { LTD } \\
\text { LTI }\end{array}$ & $\begin{array}{l}-2.23^{*} \\
-7.16^{* *}\end{array}$ & $\begin{array}{l}-3.43^{* \star} \\
-10.35^{\star \star}\end{array}$ \\
\hline Argentina, Chile, Mexico & $\begin{array}{l}1991: 01.10 \\
2000: 12 \text {. }\end{array}$ & 3 & 120 & $\frac{1 \mathrm{TO}}{1 \mathrm{TI}}$ & $\begin{array}{l}-3.44 t \\
-8.30\end{array}$ & $\begin{array}{l}-4.9 \% \\
-7.63^{\prime}\end{array}$ \\
\hline Argentina, Chile, Mexico & $\begin{array}{l}\text { 1991:01 to } \\
1995: 12\end{array}$ & 3 & 60 & $\begin{array}{l}\text { LTD } \\
\text { LTI }\end{array}$ & $\begin{array}{l}-2.62^{\star *} \\
-5.13^{\star *}\end{array}$ & $\begin{array}{l}-4.35^{* *} \\
-4.36^{* *}\end{array}$ \\
\hline
\end{tabular}

Note: * and ** reject the null hypothesis in which the series is non-stationary, at $5 \%$ and $1 \%$, respectively. $N$ represents the number of countries, and $T$ the number of temporal observations.

According to the traditional method, the choice between the fixed effect and the random effect models, to perform the UIP test was based on the econometric results obtained from the Hausman test. The results, presented in Table 3 confirm that for the group of countries composed by Argentina, Brazil, Chile, and Mexico, the fixed effects model showed to be more adequate in most of the cases. In the sub period of Jan/96 to Dec/00, however, the random effect model is a better choice.

On the other hand, for the group of countries composed by Argentina, Chile, and Mexico, the Hausman test showed that the random effects model is more indicated for the estimation. The exception is the sub period of Jan/91 to Dec/00, where the fixed effects model was indicated.

It is interesting to notice that for the group comprised of Argentina, Brazil, Chile, and Mexico the fixed effects model that was chosen for the periods of Jan/90 to Dec/0I and Jan/91 to Dec/95. However, in these same periods, if we consider just Argentina, Chile, and Mexico the successful model was the random effect. These results show that the presence of Brazil among the select countries have changed the specification of the model in these specific periods. ${ }^{3}$

The econometric results for the UIP hypothesis test for the countries under study, during the mentioned periods, can be seen in Table 4. The estimates have used either fixed or random effects, according to the results of the Hausman test listed in Table 3.

${ }^{3}$ In the next section, we comment on the significant result of the individual characteristics of Brazil in rejation to the other countries. It might explain the mixed results obtained above 
Table 3: Hausman Test

\begin{tabular}{|c|c|c|c|c|c|c|}
\hline Group & Period & $\mathbf{N}$ & $\mathrm{T}$ & Hobs\# & Pvalue & Suggestion \\
\hline $\begin{array}{l}\text { Argentina, Brasil, } \\
\text { Chile, Mexico }\end{array}$ & $\begin{array}{l}1990: 01 \text { to } \\
2001: 12\end{array}$ & 4 & 144 & 5.24 & .0220 & $\begin{array}{l}\text { Fixed } \\
\text { Elfects }\end{array}$ \\
\hline $\begin{array}{l}\text { Argentina, Brasil, } \\
\text { Chile, Mexico }\end{array}$ & $\begin{array}{l}1991: 01 \text { to } \\
2000: 12\end{array}$ & 4 & 120 & 47.37 & .0000 & $\begin{array}{l}\text { Fixed } \\
\text { Effects }\end{array}$ \\
\hline $\begin{array}{l}\text { Argentina, Brasil: } \\
\text { Chile, Mexico }\end{array}$ & $\begin{array}{l}1991: 01: 10 \\
1995: 12\end{array}$ & & 60 & 124.35 & .0000 & $\begin{array}{l}\text { Fixed } \\
\text { Elfects }\end{array}$ \\
\hline $\begin{array}{l}\text { Argentina, Brasil, } \\
\text { Chile, Mexico }\end{array}$ & $\begin{array}{l}1996: 01 \text { to } \\
2000: 12\end{array}$ & 4 & 60 & 3.00 & .0832 & $\begin{array}{l}\text { Random } \\
\text { Effects }\end{array}$ \\
\hline $\begin{array}{l}\text { Argentina, Chile, } \\
\text { Mexico }\end{array}$ & $\begin{array}{l}1990: 01.10 \\
2001.12\end{array}$ & 3 & 144 & 0.98 & .3227 & $\begin{array}{l}\text { Randorn } \\
\text { Etrects }\end{array}$ \\
\hline $\begin{array}{l}\text { Argentina, Chile, } \\
\text { Mexico }\end{array}$ & $\begin{array}{l}1991: 01 \text { to } \\
2000: 12\end{array}$ & 3 & 120 & 36.40 & .0000 & $\begin{array}{l}\text { Fixed } \\
\text { Effects }\end{array}$ \\
\hline $\begin{array}{l}\text { Argentina, Chile, } \\
\text { Mexico }\end{array}$ & $\begin{array}{l}1991: 01 \text { to } \\
1995: 12\end{array}$ & 3 & 60 & 0.84 & .3592 & $\begin{array}{l}\text { Random } \\
\text { Effects }\end{array}$ \\
\hline $\begin{array}{l}\text { Argentina, Chile, } \\
\text { Mexico }\end{array}$ & $\begin{array}{l}1996: 01 \text { to } \\
2000: 12\end{array}$ & 3 & 60 & 0.69 & .4051 & $\begin{array}{l}\text { Random } \\
\text { Effects }\end{array}$ \\
\hline
\end{tabular}

Note: Hobs represents the value observed for the Hausman test, $N$ represents the number of cross-section units (countries), and ' $T$ the number of temporal observations

\section{Panel data results}

In Table 4, we can observe a complete rejection of the uncovered interest parity for the group comprised of Brazil, Argentina, Mexico, and Chile, indicating an absence of correlation between the set of domestic interest rates and the set comprised of international interest rates and exchange rates for each country. The $\beta$ estimator showed to be statistically different from 1 , or statistically null, or yet with negative signal, indicating a possible inverse correlation between the set of domestic interest rates and the set of international interest rates and exchanges rates of each country.

However, the econometric results do not reject the validity of the UIP for the group comprised of Argentina, Chile, and Mexico, for the sub periods of Jan/91 to Dec/00, and Jan/91 to Dec/95, given the statistically significant values of $\beta, 1.15$ and 1.42 , respectively, and the non-rejection of the null hypothesis that $\beta=1$, at the $5 \%$ level of significance. The results of this subgroup, during the same sub periods, also indicate the existence of a high degree of capital mobility.

Notice that the group comprised of Argentina, Brazil, Chile, and Mexico had the UIP hypothesis rejected for every period. The 
results suggest that the inclusion of Brazil in the group must have affected the final result. We can observe that, in the estimations, the significant result of the individual characteristics of Brazil in relation to the other countries might indicate, a greater sensitivity of the Brazilian domestic variables to the constant world financial-economic crises during the period under study. Furthermore, possible evidence that the levels of the non-measurable variables in Brazil, such as political uncertainty and risk premium, were greater than in Argentina, Mexico, and Chile. ${ }^{4}$

The group composed by Argentina, Chile, and Mexico also had the UIP hypothesis rejected for two periods. Most of the financial and cambial crises of the 90's occurred in the sub period of Jan/96 to Dec/00. There were, for instance, the Asian crises in 1997/98, the Russian crises in 1998, and the Brazilian crises in 1999. Those crises lead to great oscillations in the series of the exchange and interest rates in the countries with floating rates. Particularly, the Latin American countries were very sensitive to those crises. On the contrary, the period of economic and financial stability for the Latin American ${ }^{5}$ countries, from Jan/90 to Dec/91, did not have the UIP hypothesis rejected. The longer period, from Jan/90 to Dec/01, is characterized by jumps in Argentine interest rates in $1990 .{ }^{6}$ This behavior of the interest rates might have biased the rates of Chile and Mexico. This can explain the fact that the sub period, which took of this year, did not have the UIP hypothesis rejected. In this case, one can observe that the period from Jan/91 to Dec/00 did not reject the UIP hypothesis.

\section{Conclusion}

The results of the econometric tests with panel data did not reject the validity of the UIP for the group comprised of Argentina, Chile, and Mexico, for the sub periods of Jan/9I to Dec/00, and Jan/91 to Dec/95. Additionally, this group's results, for the sub periods mentioned, indicate the existence of a high degree of capital mobility.

${ }^{4}$ See Table 4.

5 This period was marked by the Mexican crises in December of 1995.

- This can be confirmed by looking at the IMF statistics. 
Table 4: Panel Data Results: Argentina, Brazil, Chile, and Mexico

\begin{tabular}{|c|c|c|c|c|c|c|c|c|c|}
\hline Group & Period & $\begin{array}{c}\alpha \\
\operatorname{Arg}\end{array}$ & $\begin{array}{c}\alpha \\
\operatorname{Bra}\end{array}$ & $\begin{array}{c}\alpha \\
\text { Chi }\end{array}$ & $\stackrel{\alpha}{\operatorname{Mex}}$ & $\begin{array}{c}\alpha \\
\text { Group }\end{array}$ & $\begin{array}{c}\beta \\
\text { Group }\end{array}$ & $\begin{array}{l}\text { UIP } \\
\text { Hypothesis }\end{array}$ & $\begin{array}{l}\text { Capital } \\
\text { Mobility }\end{array}$ \\
\hline \multirow[t]{4}{*}{$\begin{array}{l}\text { Argentina, } \\
\text { Brazi, Ghile. } \\
\text { and Mexico }\end{array}$} & $\begin{array}{l}1990.01 .10 \\
2001 / 12\end{array}$ & $(0954)$ & $\left(120^{\prime}\right.$ & $\left(\begin{array}{l}1468 \\
0954)\end{array}\right.$ & $(0954)$ & . & $\begin{array}{l}0509 \\
(1,108)\end{array}$ & Relected & low \\
\hline & $\begin{array}{l}1991: 01 \text { to } \\
2000: 12\end{array}$ & $\begin{array}{l}1236 \\
(.0661)\end{array}$ & $\begin{array}{l}1.22^{\star \star} \\
(.0660)\end{array}$ & $\begin{array}{l}148^{* *} \\
(0661)\end{array}$ & $\begin{array}{l}216^{\star \star} \\
(.0661)\end{array}$ & - & $\begin{array}{l}-21^{* \star} \\
(.0708)\end{array}$ & Rejected & Low \\
\hline & $\begin{array}{l}199101.10 \\
1995.12\end{array}$ & $\left(\begin{array}{l}1665 \\
(0959)\end{array}\right.$ & 2.227 & $\left(\begin{array}{l}1630 \\
(0959)\end{array}\right.$ & $(0959)$ & . & $\left(\begin{array}{l}155^{\circ} \\
(0730)\end{array}\right.$ & Aejected & Low \\
\hline & $\begin{array}{l}1996: 01 \text { to } \\
2000: 12\end{array}$ & & & & & $\begin{array}{l}161^{* *} \\
(.0296)\end{array}$ & $\begin{array}{l}-1125 \\
(0805)\end{array}$ & Rejected & Low \\
\hline \multirow[t]{4}{*}{$\begin{array}{l}\text { Argentina, } \\
\text { Chile and } \\
\text { Mexico }\end{array}$} & $\begin{array}{l}1990.01 \mathrm{to} \\
2001.12\end{array}$ & & & & ?.t? & $(.1253$ & $\begin{array}{l}6.76^{* *} \\
(7397)\end{array}$ & Rejected & low \\
\hline & $\begin{array}{l}1991: 01 \text { to } \\
2000: 12\end{array}$ & $\begin{array}{l}.056^{\star \star} \\
(.0128)\end{array}$ & $\begin{array}{l}079^{\star \star} \\
(0129)\end{array}$ & $\begin{array}{l}14^{* *} \\
(0135)\end{array}$ & $\begin{array}{l}056^{\star *} \\
(.0128)\end{array}$ & - & $\begin{array}{l}1.15^{\star *} \\
(.1659)\end{array}$ & $\begin{array}{l}\text { Not } \\
\text { Rejected }\end{array}$ & High \\
\hline & $\begin{array}{l}1991.0110 \\
1995.12\end{array}$ & & & & & $\left(0982^{\circ}\right.$ & $\left(\begin{array}{l}42 \\
(2266)\end{array}\right.$ & Not & High \\
\hline & $\begin{array}{l}1996: 01 \text { to } \\
2000: 12\end{array}$ & & & & & $\begin{array}{l}16^{\star \star} \\
(.0477)\end{array}$ & $\begin{array}{l}-52^{\star *} \\
(.1752)\end{array}$ & Rejected & Low \\
\hline
\end{tabular}

Note $1:$ and $* *$ indicate the rejection of the null hypothesis in which the coefficient is statistically insignificant at $5 \%$ and $1 \%$, respectively. The values in parenthesis represent the standard deviation.

Note 2: We noted the absence of autocorrelation by using the modified Bhargava et al, Durbin-Watson, and Baltagi-Wu LBI tests.

In the UIP test for the group comprised of Argentina, Brazil, Chile, and Mexico the econometric results indicate, for the proposed overall period of this study, as well as for the sub periods indicated in this study, the rejection of the uncovered interest parity.

\section{Appendix}

We shall use the domestic interest rates of each country and the Treasury Bill as international interest rate according to Table 1, while the exchange rate shall be represented by the official exchange rate of each currency in relation to the US dollar. The sample contains average monthly data obtained from the sources listed in Table 1. 
Table 1: Variables Used in the Estimation of Models

\begin{tabular}{lll}
\hline Country & Interest Rate & Sources \\
\hline Argentina & Argentine Money Market Interest Rate & IPEA \\
Brazil & Over Selic & BCB \\
Chile & $\begin{array}{l}\text { Interest Rates for Instruments of the Central Bank of } \\
\text { Chile (PDBC) }\end{array}$ & IPEA \\
USA & Treasury Bill, 3-month & FED \\
Mexico & $\begin{array}{l}\text { Bond Interest Rate (CETES91), except for Aug/96, } \\
\text { Sep/96 and Nov/98 for which CETES28 was used }\end{array}$ & BANXICO \\
\hline
\end{tabular}

\section{Bibliography}

ALEXIUS, A. (2001). Uncovered Interest Parity Revisited. Review of International Economics 9, 505-17.

ALIBER, R.Z. (1973). The Interest rate parity Theorem: A Reinterpretation. Journal of Political Economicy 81, p.1451-59.

BAILLIE, R.T and OSTERBERG, W.P. (2000). Deviations from Daily Uncovered Interest Rate Parity and the Role of Intervention. Journal of International Financial Markets 10 , 363-79.

BANXICO. Banco de México Available from www.banxico.org.mx, access in July, 2002. BCB - Banco Central do Brasil. Available from www.bcb.gov.br, access in July, 2002 BERK, J. M. and KNOT, K.H.W. (2001). The Term Structure of UIP: Evidence from Survey Data. Applied Economics Letters 8, 459-62.

CHINN, M. and MEREDITH, G. (2000). Testing Uncovered Interest Parity at Short and Long horizons. <http://econ.ucsc.edu/ faculty/Chinn/UIP> Access in: 06 ago. 2001.

CRISTENSEN, M. (2000). Uncovered Interest Parity and Policy Behavior New Evidence. Economics Letters 69, 81-87.

FED - The Federal Reserve. Available from www.federalreserve.gov, access in July, 2002.

FLOOD, R. P. and ROSE, A. K. (2001). Uncovered Interest Parity in Crises: The Interest Defense in the 1990s. IMF Working Paper WP/01/207, International Monetary Fund.

FRANCIS, B.B. HASAN, I. and HUNTER, D. (2001). Emerging Market Liberalization and the Impact on Uncovered Interest Rate Parity. X Tor Vergata Conference 5-7, Rome, Italy.

FRANKEL, J. A. (1992). Measuring International Capital Mobility: A Review. The American Economic Review 82, 197-202.

GREENE, W. H. (1997). Econometric Analysis. Prentice-Hall: United States of America. IM, K. S.; PESARAN, M. H. e SHIN, Y. (1997). Testing for unit roots in heterogeneous panel Manuscript, Department of Applied Economics, University of Cambridge.

IPEA - Instituto de Pesquisas Econômicas Aplicadas. Available from www.ipeadata gov.br, access in July, 2002. 
KHOR, H. E. and ROJAS-SUAREZ, L. (1991). Interest Rates in Mexico. IMF Staff Papers 38, 850-871.

KRASKER, W. S. (1980). The "Peso Problem" in Testing Efficiency of Forward Exchange Markets. Journal of Monetary Economics 6, 269-76.

LEVIN, A. and LIN, C. F. (1992). Unit Root Test in Panel Data: Asymptotic and Finite Sample Properties. Discussion Paper \#92-93, University of California at San Diego.

MONTIEL, P. J. (1994). Capital Mobility in Developing Countries - Some Measurement Issues and Empirical Estimates. The World Bank Economic Review 8, 1-57.

SACHSIDA, A.; ELLERY JR., R. and TEIXEIRA, J.R. (2001). Uncovered Interest Parity and Peso Problem: The Brazilian Case. Applied Economics Letters 8, 179-81. 